\title{
Function of Traditional Music Karo Gendang Lima Sedalanen in Implementation of Erpangir Kulau Ceremony
}

\author{
Octaviana Tobing \\ Faculty of Language and Art, State University of Medan, Medan, Indonesia \\ octato17@gmail.com
}

\section{Abstract}

Erpangir kulau is a term or name created by the Karo community to express a tradition of religious ceremonies or self-cleansing rituals in the Karo community, which uses Karo traditional music, ensemble Gendang Lima Sedalanen, as a supporting element of its implementation. The purpose of this study was to determine the Function of Traditional Music Karo Gendang Lima Sedalanen in Implementation of the Erpangir Kulau Ceremony. The results showed that the five functions according to the Kustap theory were fulfilled by the use of the ensemble Gendang Lima Sedalanen. In its function as an emotional expression, it can be seen from how the ensemble has a strong energy to bring out the emotions of all the actors involved in carrying out the religious ceremonial activities, so that various attitudes of the ceremonial participants appear. Whereas in its function as a communication is realized during the ongoing communication between guru sibaso who act as a medium between the spirit that is believed to be present, and the people who carry out pangir. Furthermore, the function of Gendang Lima Sedalanen as a social response arises from how the entire Karo community with various temperaments, but can unite to carry out this ceremony. When it functions as a cultural preservation fulfilled through its use in the ritual Erpangir Kulau ritual, it is a form of appreciation and love for their culture. Finally, in its function as a symbol representation is realized through guru sibaso who is a symbol of someone who has his own expertise or prestige.
Keywords

Gendang lima sedalanen; fungsi;

erpangir kulau

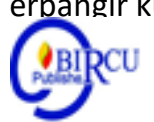

\section{Introduction}

Culture can be realized in various ways, one of which is through art. This part cannot be separated from how a society runs its daily life, people are always present in the activities of the religious system, customs, and even entertainment. The beauty of a sense of art becomes an inseparable part in accompanying their various activities, both in community groups and individually. This is in line with the opinion of Koentjaraningrat (1987: 9) which states that: "Culture in principle is all the result of human cultivation in overcoming life's difficulties and arousing his life to realize true happiness. While culture itself means the whole of human ideas and work, which must be familiarized with learning ". This shows that actually art as an expression of a sense of beauty, is one of human needs that is essential and universal. Art that is manifested in four major parts, such as fine arts, theater, dance, and music will be maintained and developed by the supporting community, one of them is the Karo community.

Karo ethnic is one of many ethnics and sub-ethnic ethnic groups which is in North Sumatra. The cultural system of Karo's community is related to its kinship system. In addition, his artistic culture is also very closely related to the kinship system in his community. Some elements of karo community culture are music, literary art (folklore, 
pantun), dance and art (painting, chisel or carving). In Karo society, art has become a very important tradition and is still practiced for generations to its generation. (Ginting, 2019)

Karo ethnic is one of eight indigenous ethnic groups living in North Sumatra Province. The eight native ethnic groups living in North Sumatra are Melayu, Batak Toba, Batak Karo, Mandailing, Batak Simalungun, Batak Pakpak, Nias, Batak Pesisir (Central Tapanuli) and one of five Puak Batak that is Batak karo. The five Batak groups are: Batak Toba, Batak Pesisir, Batak Simalungun, Batak Pakpak, and Batak Karo. Like other ethnic groups, Karo ethnic also has their own uniqueness or tradition. The varieties of arts that are also part of the traditions of community life include music, fine arts, dance, and theater. The implementation of these artistic activities has a close relationship with the activities of people's lives. In other words, the implementation of these artistic activities has a meaningful function essential for the survival of the local community, as demonstrated by the use of traditional music at various traditional ceremonies. In this case, music becomes an expression of their spiritual aspirations.

The music can be in the form of instrumental music, vocal music, or a combination of the two. Karo people call music the term drum. And in Karo society the drum itself has several meanings, including; 1) drum, as an understanding to indicate a certain type of music (gendang Karo), 2) drum, as the name of a musical instrument (gendang singindung, gendang singanaki), 3) drum, to indicate a particular type of song or composition (gendang peselukken), 4 ) drum, to show certain musical ensembles (gendang lima sendalanen, gendang telu sendalanen), 5) drum, to interpret a particular ceremony (gendang cawir metua, gendang guro-guro aron). In addition, the Karo community also has several types of music that are usually used in traditional arts. There are musical instruments that are played together (ensemble), those that are played solo. In addition to musical instruments, there are also several vocal music genres (songs), both sung solo, and accompanied by musical instruments.

Karo ethnic is one of the many ethnic groups that has several traditional ceremonies and rituals that are still frequently performed. In the tradition of the Karo tribe there are two ceremonial terms, namely tribe ceremonies (marriage customs, funeral customs, customs for children, adolescents, and parents, traditional land and agriculture) and ritual ceremonies (Erpangir Kulau ceremonies, raleng tendi ceremonies, Muncang ceremonies, and so on). One ceremony that always includes music in its implementation is the Kulau Erpangir ceremony. Erpangir Kulau is one of the ritual ceremonies originating from the Karo tribe community. Erpangir comes from the word pangir, which means shower or water. Erpangir kulau is a term or name made by the Karo people to declare a religious ceremony or ritual of cleansing that is carried out by bathing the whole body using herbs and flowers in the river with the aim of thanksgiving ceremony to Dibata (the name of God in the Karo language), avoiding a catastrophe that might occur (this is usually preceded by a hunch or nightmare), achieve a certain desire or purpose. Sometimes the Erpangir Kulau ceremony is carried out as an effort to ask for something from Dibata (God). Then to cure an unusual disease. Erpangir ceremonies are sometimes carried out as an attempt to treat a certain type of non-medical illness, such as treating a lunatic, or healing people who are attacked by begu (the term to declare Satan in Karo language), or diseases caused by other satanic disorders. Usually this activity is carried out by the Sibaso teacher group on a regular basis within a month or once a year. The ritual ceremony is a sign of respect for the jinujung (supernatural powers that accompany it in carrying out activities as a guru sibaso). In addition to the guru sibaso)., some Karo traditional musicians who still believe in silengguri (the supernatural power that 
accompanies them in their profession as Karo traditional music artists), also participated in Erpangir Kulau at certain times.

According to Ginting (1999: 38):"Erpangir kulau is floating or bathing in the river to wash. In ancient times, Karo people held a party of Erpangir Kulau (mooring) for a celebration, including: (1) Sukut which was planning to good luck, (2) because it was just released from danger, for example there were those who had recovered from illness, (3) strengthening the prestige, recognizing one's position in the middle of the family (sangkep ngeleluh), (4) so that other people see their family wealth (show force) ".

The Erpangir Kulau ritual is always accompanied by traditional Karo music, namely the gendang lima sedalanen (gendang in this case means "musical instrument", lima means "five", and Sedalanen means "in line" or together "or telephones sedalanen. Sometimes gendang lima sedalanen are also called gendang sarune.The existence of two terms or the mention of the same traditional karo musical ensemble (gendang lima sedalanen and gendang sarune) occurs because of differences in the background of the people who use it. more often used, while in various writings on karo music culture more use the term gendang lima sedalanen. For the consistency of writing, in this case the term gendang lima sedalanen is used. This does not mean that the term gendang lima sedalanen is more representative than gendang sarune because indeed the two terms it is often used in t Karo community radiations. Gendang lima sedalanen is a set of traditional karo ensembles or musical instruments consisting of sarune, gendang singanaki, gendang singisai, gung, and penganak. Gendang lima sedalanen is used as accompaniment music in various traditional ceremonies and rituals such as the erpangir kulau ceremony. In this regard, it is clearly seen that music has an important function and role in the implementation of the ritual erpangir kulau. The word function often has different meanings in different contexts. In general, functions (music) are understood as benefits or uses. Sedyawati (2006: 293) states: "the function of the performing arts, both through past data, as well as present-day ethnographic data, includes religious functions, confirmation of social interaction, education, and entertainment". Meanwhile, according to Ali's opinion (2006: 15): "in general the function of music in Indonesian society is, among others, as a means of cultural ceremonies, entertainment, self-expression, economics, communication, and dance accompaniment. In addition, Kustap (2008: 8-11) explained that: "the function of music in society includes the function of emotional expression, aesthetic connoisseur function, entertainment function, communication function, social response function, cultural preservation function, unifying function of the nation, trade promotion function, symbol representation function.

\section{Discussion}

Erpangir Kulau is a big ceremony for the Karo people, based on the traditional beliefs of the Karo people, namely pemena according to Bangun (1986: 57). This ceremony contains certain objectives such as healing disease, avoiding catastrophes that might occur, finding a mate, getting a job and all other good things. To get results in accordance with the objectives of the erpangir kulau, guru sibaso were invited to read the good and bad days (the Karo people call it simeteh wari telupuluh). This is done because the Karo people still believe that there are certain days that are considered very good and appropriate to carry out the ritual because they still think that not all days are good and right to carry out this ritual. Based on the available days, the best day to perform the erpangir kulau ritual according to the community is: 1) Nggarasimbelin, 2) Aditia turun, 3) Beraspati tangkep, 4) Cukera dudu (lau), 5) Belah purnamaraya, dan 6) Nggaraenggotula.. The sixth day they believe this is a very good day according to the belief of sidekah (old) to perform the ritual erpanggir kulau. 
Usually at this ceremony they must first determine the day that feels good, then it is determined who will be the teacher (mediator) who will later create a barrier or an antidote to misfortune. All 'sangkep nggeluh sukut' are invited to carry out this ritual. Erpangir kulau does not only have the meaning of cleansing the body, but also the ritual cleaning of magical, mystical and animistic work that is still associated with intensely in the course of its implementation, because the old beliefs of the Karo people, pemena still have a big influence.

The sacred ceremony was held in the river. In carrying out the erpangir kulau ceremony, there are several criteria in the selection of rivers that will be used as a place to carry out the ritual, namely the implementation of the erpangir kulau ceremony carried out in a flowing river, in a two-pronged river, or in a river that has been built into a special place as a place to carry out erpangir kulau rituals, such as Lau Debuk-debuk, Lau Penda, Sembahe, and there are several more rivers around Tanah Karo that can also be used. After the kulau erpangir is finished, it is continued by holding a party or thanksgiving in jambur (the term Karo community which means meeting hall) which is available in every residential area. The Karo people almost never carry out large activities in their homes, but do so in jamburjambur.

Usually this ritual requires some material that is used to erpangir kulau (bathing shampoo), including:

1) Pangir (water for bathing shampoo).

The main ingredient of pangir is water mixed with rimoukur (kaffir lime), special leaves taken from the forest, and fragrant oils. The amount of pangir water is adjusted to the number of people who will cry out or want to be ritualized.

2) Belo cawir.

Belo cawir is a term for betel leaf that does not have a defect or can be said to be a perfect betel leaf. Betel leaf is called sawir if the betel leaf is old enough, has no tears in the leaves, no black spots, and not dirty. In addition, the betel has a reddish back side fiber. If it is green, it is not categorized as betel, but is called gatap. In addition, this betel leaf is also equipped with other equipment into a single unit, namely mbako tabeh (good quality tobacco), mayang (areca nut that tastes good and has been split), choice betel lime, gamber (clean gambier), and often equipped with cigarettes. These cigarettes are used as offerings to the spirits that are believed to come at the ceremony. Usually the cigarette is smoked by the medium or teacher, as a sign that the spirit has come to the ceremony. Belo cawir was given to the teacher, to be assisted in carrying out my erpangir kulau ceremony from start to finish.

3) Cimpa.

Cimpa is a traditional Karo traditional cake made from glutinous rice flour which contains a core consisting of shredded coconut, brown sugar and ginger that functions to warm the body. The spleen is usually wrapped in singkut leaves and also usually cooked by steaming. Cimpa must be provided in every traditional Karo event. This spleen is usually used as food, but can also be used as an offering to certain spirits. If in one of the traditional events the spleen is not served, then the customary event is deemed to be deficient and imperfect.

The implementation of this ritual uses traditional music, gendang lima sedalanen as an inseparable part. The drum of gendang lima sedalanen is one of the traditional types of Karo music in addition to gendang lima sedalanen. Literally, the word 'drum' on gendang lima sedalanen means a musical instrument, five means five (5), and sedalanen means in line. This ensemble consists of five musical instruments, namely: 1) Sarune; is a musical instrument used by blowing it. This instrument has a double tongue (double reed), and the tube is a conical instrument similar to an oboe. This instrument consists of five parts which can be separated and made of different materials, namely; a) sarune children, b) tongkeh, $c$ ) 
ampang-ampang, d) batang sarune, and e) gundal. 2) Gendang Singanaki; is a musical instrument used by being hit which produces three types of sounds namely: tang, cek, and kok. This instrument is made from jackfruit tree wood. On both sides of the conical-shaped musical instrument there are membranes spiced from animal skins. The front side or the part that is hit is called gendang babah, while the back / bottom side is called gendang pantil, 3) Gendang Singindungi; is a membrane musical instrument (membranophone) in the form of a double conical (single head conical drum). Gendang singendang produces two types of sounds namely: pliers and tih 4) Penganak; is a musical instrument that is played by hitting a pencu in the middle, this instrument has a mini size that is $16 \mathrm{~cm}$ in diameter and 5) gung; namely a musical instrument that is classified as a type of suspended idiophone that has a feeling with a child, it's just that the two instruments have differences in terms of size. Gung has a wider diameter $(68.5 \mathrm{~cm})$ and is made of brass. Thus, gendang lima sedalanen drum contains the meaning of five instruments that are played in line or together.

In this gendang lima sedalanen consists of four to five personnel or players. And each player has their own position and name or nickname, that is, for people who play Sarune, the local people call it Penarune, for those who are in charge of playing the drum, they are given the name of a singer. for those who are in charge of playing Penganak they call it Simalu gung. In general, the five-drum drummer in each performance plays in a seated position.

This sitting position, especially for penarune and penggual, is a standard position for several reasons namely; 1) In producing certain notes, the penarune must close the tip of the sarune (tonggum) to the calf of her own foot. 2) the seller always connects his instrument (gendang singanaki and gendang singidungi) between his legs in a sitting and cross-legged position, so that the instrument's position becomes diagonal, with the drum pointing to the right side of the seller. 3) Simalu gung and Simalu Penganak also play in a sitting position, while the two instruments are always hung by a string in a place that has been specifically provided. Gendang lima sedalanen is a type of ensemble that is widely used in various activities and activities of the Karo community, such as in the implementation of traditional ceremonies, rituals, or just as entertainment. In various activities, it can be observed how the use and function of Gendang lima sedalanen. The words 'use' and 'function', although they can be said to have the same meaning, actually have different meanings. In the case of the use of music at the erpangir kulau ceremony, it is interpreted as the use of ensemble Gendang lima sedalanen to accompany the erpangir kulau ceremony. While the word 'function' is related to the reason why the user is doing. In terms of the function of music at the erpangir kulau ritual, it is understood as a goal that can be demonstrated by the presence of gendang lima sedalanen.

The function of ensemble gendang lima sedalanen at the erpangir kulau ceremony as an emotional expression can be seen from how the ensemble has strong energy to bring out the emotions of all actors involved in carrying out the ceremonial activities. Expressed through the movement of the body of the perpetrator to follow the rhythm of the music while feeling the 'trust' and 'spirit' (tendi). In addition, emotional expression is also manifested at the moment of 'temptation', namely the delivery of prayer and hope.

The communication function shown by the drum of gendang lima sedalanen in the erpangir kulau ceremony is when the communication takes place between the guru sibaso teacher who acts as the medium between the spirit that is believed to be present, and the people who carry out the pangir. In this case, communication is defined as the process of delivering something to the intended. The 'delivery' process was successful because it was supported by certain means, namely music. Music is one of the holders of an important role in the process of the ritual erpangir kulau ritual. In addition, the sound produced by the ensemble aims to give a signal to the performers of the ceremony in order to run smoothly according to the actual stages. 
Furthermore, the function of social response can be seen from how the entire Karo community united to carry out this ritual ceremony. People who are around the location of the ceremony will gather to see or witness the implementation of this ceremony, when they hear the sound of gendang lima sedalanen. The gathering of people as a result of hearing the sound of the drum of gendang lima sedalanen, to witness the erpangir kulau ceremony showed a social response. Thus, the social response from the surrounding community due to hearing the sound of music confirms that this ensemble can be an alternative unifying Karo community.

The function of cultural preservation is also shown by this ensemble which is proven by its use in the erpangir kulau ceremony, which is a form of appreciation and love for the variety of cultures belonging to the Karo tribe community. With the use of ensemble gendang lima sedalanen in the ceremony, the process of cultural preservation is ongoing and symbol representation by the ensemble is seen in how the Sibaso teacher takes an important role in controlling the process of carrying out the kulau erpangir ceremony. Guru sibaso is a symbol of someone who has his own expertise because he can work as a medium of communication between sibaso and tendi (soul), which emerges as a ceremonial medium in collaboration with the music of gendang lima sedalanen.

\section{Conclusion}

Based on the explanation that has been described, it can be concluded that the gendang lima sedalanen as part of Karo traditional music which has important control and function in carrying out the ritual erpangir kulau ritual. The theory of music function delivered by Kustap has been proven through an explanation in the contents section.

\section{References}

Ali, Matius. (2006). SeniMusik SMA Kelas XII. Jakarta: Erlangga

Bangun,Trida. (1986). Manusia Batak Karo. Inti Idayu Press

Gintings, EP. (1999). Religi Karo (membaca Religi Karo Dengan mata Yang

Baru).Kabanjahe: Abdi Karya.

Ginting, P. (2019). Music Creation Based on Folklore. Budapest International Research and Critics Institute (BIRCI-Journal), p. 271-278

Koentjaraningrat. (1985). Metode-metode Penelitian Masyarakat. Jakarta : Gramedia.

Kustap, MohMitaqin. (2008). Seni Musik Klasik Jilid 1 untuk SMK. Jakarta: Direktorat

Pembinaan Sekolah Menengah Kejuruan, Direktorat Jenderal Manajemen Pendidikan

Dasar dan Menengah, Departemen Pendidikan Nasional.

Merriam, Alan P. (1964). The Anthropology of Music. Chicago: Northwestern University Press

Sedyawati, Edi. (2006). Pertumbuhan Seni Pertunjukan. Jakarta : Sinar Harapan 